\title{
LANDSLIDES HAZARD ASSESSMENT USING DIFFERENT APPROACHES
}

\author{
Cristina COMAN - PhD Student, Technical University of Civil Engineering \\ Sanda MANEA - Pofessor, PhD, Technical University of Civil Engineering
}

\begin{abstract}
Romania represents one of Europe's countries with high landslides occurrence frequency. Landslide hazard maps are designed by considering the interaction of several factors which, by their joint action may affect the equilibrium state of the natural slopes.

The aim of this paper is landslides hazard assessment using the methodology provided by the Romanian national legislation and a very largely used statistical method.

The final results of these two analyses are quantitative or semi-quantitative landslides hazard maps, created in geographic information system environment. The data base used for this purpose includes: geological and hydrogeological data, digital terrain model, hydrological data, land use, seismic action, anthropic action and an inventory of active landslides.

The GIS landslides hazard models were built for the geographical area of the Iasi city, located in the north-east side of Romania.
\end{abstract}

Keywords: landslides, hazard, susceptibility, GIS, bivariate analysis

\section{Introduction}

The natural landslide hazard is a potentially destructive physical event, where the circumstances may cause properties destruction, a negative social and economic impact, environmental degradation and even injury or loss of life. Landslides hazards can have natural triggers or can occur due to human activities [1].

The first landslide hazard maps have been made in the proximity of 1970 [2]. Landslides hazard zonation allows delineation between stable areas and unstable or potentially unstable area.

In the national and international scientific literature valuable documents can be found regarding the landslide hazard assessment and the mapping methods. However, there is no standardized method in view of achieving these maps. They can be designed using various approaches and methodologies, depending on user requirements, assessment purposes, the mapping scale factor and very importantly, the quality of available data.

In the last two decades, due to collecting and automatic processing data, significant developments have been noted. Many computer programs are available, which are able to process high complexity operations.

Also called instability map or failure probability map, the landslides hazard map is a site plan of the study area, divided into polygons characterized by the same degree of instability (to a conveniently chosen scale).

According to „Law 577/2001 regarding National Territory Arranging Plan - Section V, natural risk areas", at national level, there is an accepted methodology for landslides hazard zonation [3]. This methodology of hazard assessment considers eight fundamental criteria for landslides analysis: lithological, geomorphological, structural, hydrological and climatic, hydrogeological, seismic and land use [3] [4].

The statistical methodology used for this GIS model is the bivariate susceptibility analysis for landslides assessment, based on active events inventory. 
Many authors claim that a hazard event requires (besides spatial distribution) assessing the probability of occurrence for a particular process with a certain magnitude [5] [6] [7].

Therefore, in order to achieve a landslide hazard, it is necessary to specify a time interval for potential events and also the magnitudes/intensities associated. Without an estimate of the likely timing of landslides occurrence, expressed as an annual frequency of events and without a certain level of magnitude, the users cannot make a quantitative estimate of hazard and the assessments remain only as a susceptibility evaluation (spatial probability) [8].

In the last few years, multiple landslides hazard mapping programs were developed, using both approaches mentioned above, in the framework of some National Plans.

This paper will focus on applying these two methods in a case study located in the Romanian city Iasi. The leading objectives of the paper work are providing theoretical and practical overviews on landslides hazard assessment.

\section{Natural and anthropic conditions influencing natural landslide hazard}

From the morphological point of view, the landforms of Iasi city are represented by hilly areas with maximum altitudes between 100 and $370 \mathrm{~m}$. The natural landscapes consist of high fields bordered by hills or interfluvial hills with steep slopes, some affected by erosions and landslide processes characterized by extremely active morphodynamics.

The vulnerability of the study area, located in the Moldavian Plain, subunit of the Moldavian Plateau, reveals an area with high potential of landslides manifestation, sometimes with great magnitude and generating significant damage.

In the recent decades the municipality has carried out extensive work to reduce the landslides risk for Iasi city but the instability potential is still high.

Over time, numerous areas with high landslides occurrence have been registered in Iasi, among which areas such as Eastern side of the Copou Hill, the segment between Sararie and Ticau, the right overbank of the Cacaina river, the Bucium Hill, the Galata district and the Niculina district are mentioned. Those downhill displacement processes, attained severe proportion in the early twentieth century, most likely due to the beginning of slope deforestation and development of the inhabited area. The removal of a forest or stand of trees and the human interventions (anthropic actions) on the natural slopes are two main causes that favor instability phenomena.

Previously only few examples of the morphodinamic manifestations in the Iasi region were presented, but the complexity of the current situation requires further actions to diminish the landslides occurrence, which include multiple works, extensive consolidation of the slopes, rigorous measures for stopping the construction of new buildings, groundwater and surface water control and also the extension of monitoring activities.

From the geotechnical point of view, the soils layered in the study area have the following general stratification: under the topsoil layer with the maximum thickness of about $3 \mathrm{~m}$, a succession of cohesive materials like clay, silty clay or silt with clay fractions, sandy clays, having semi-solid consistency or plastic consistency, placed on a sandstone bedrock can be observed.

Sandy clay, silty clay or clay with small sands lens are generally found in the rivers floodplains. Clay and silty clays, with plastic consistency are generally found in the hilly areas.

Through its physical and mechanical properties, silty clay is considered a conducive environment for slip surface occurrence and slope failure.

The main trigger factor of slope failure is the presence of water (groundwater or surface water) by increasing tangential forces along the sliding plane. 
The groundwater table of the Iasi region, have a very unsteady distribution and it was found in permeable lenticular deposits at depths between $0-10 \mathrm{~m}$ in the north side of Bahlui river and 0 $20 \mathrm{~m}$ in the southern side.

This happens due to the particular diversity of supply sources, which come from groundwater discharges through streams located in terraced land, springs from Sarmatian layers (south of Bahlui especially) and rainfall waters.

The annual rainfall conditions are represented by the continental climate regime, with multiannual averages of approximately $518.9 \mathrm{~mm}$ at Airport Station and $514.8 \mathrm{~mm}$ at High School Negruzzi Station, with minimum levels in February $(25.9 \mathrm{~mm})$ and March $(23.8 \mathrm{~mm})$ and maximum levels in June (70.4 and $76.7 \mathrm{~mm})$. The highest average daily amount of rainfall was recorded in June $(2.2 \mathrm{~mm})$ and the lowest in March $(0.8 \mathrm{~mm})$ and December $(0.9 \mathrm{~mm})$. Over the years, the thickness of the snow layer has decreased. In the winter of 1931-1932 the highest accumulated snow layer of approximately $195 \mathrm{~cm}$ was recorded. The average annual temperature is approximately 9-10 degrees.

The rainfalls with long periods and slow discharge, the melted snow accumulations and the freeze - thaw processes are the major causes generating landslides.

\section{Landslide hazard zonation using the methodology provided by Romanian national legislation}

Landslide hazard map is also known as mean hazard rate map $\left(\mathrm{K}_{\mathrm{m}}\right)$ [3] [4].

The mean hazard rate map is obtained by overlapping 8 thematic maps using the following mathematical equation:

where:

$$
K_{m}=\sqrt{\frac{K_{a} * K_{b} *\left(K_{c}+K_{d}+K_{e}+K_{f}+K_{g}+K_{h}\right)}{6}}
$$

$\mathrm{K}_{\mathrm{a}}$ - Lithological criterion (factor) map;

$\mathrm{K}_{\mathrm{b}}$ - Geomorphological criterion (factor) map;

$\mathrm{K}_{\mathrm{c}}$ - Structural criterion (factor) map;

$\mathrm{K}_{\mathrm{d}^{-}}$Hydrological and climatic criterion (factor) map;

$\mathrm{K}_{\mathrm{e}}$ - Hydrogeological criterion (factor) map;

$\mathrm{K}_{\mathrm{f}}$ - Seismic criterion (factor) map;

$\mathrm{K}_{\mathrm{g}}$ - Land use criterion (factor) map;

$\mathrm{K}_{\mathrm{h}}$ - Anthropic criterion (factor) map.

Thematic maps will be achieved by providing weights for each factor, in a range between 0 and 1 . 0 means no landslides occurrence probability and 1 means very high landslides occurrence probability [4].

Thematic maps will be processed and overlaid using geographic information systems tools, following Stereo 70, S42 Romania coordinate system.

\subsection{Lithological factor map}

From the geological point of view, Iasi city is located in a major structural unit, Moldavian Platform. Moldavian Platform is a geological unit laid in front of the Eastern Carpathians, which is bounded on the surface by Carpathian fault. Most of the relief platform consists of Sarmatiene formations (clays and sands with limestone and sandstone intercalations). 
Using The Geological Map of Romania Territory, scale 1:200000, three lithological zones are identified for Iasi city:

- Pleistocene (qp3) represented by terrace deposits, widely developed on the left bank of Bahlui river;

- Bessarebian (bs), represented by clay marl, low salinity deposits of clay marl, clay and sandy clay, sands, sandstones, present in most part of the administrative territory;

- Holocene (qh2) represented by the alluvial deposits of the rivers floodplains, consisting of small gravel, rough, medium and fine sand and sandy clay. These deposits contain an aquifer protected by impermeable clays.

Lithological factor map results from assigning values to $\mathrm{K}_{\mathrm{a}}$ criterion as follows: 0.7 for Bessarebian, 0.8 Pleistocene and 0.95 for Holocene.

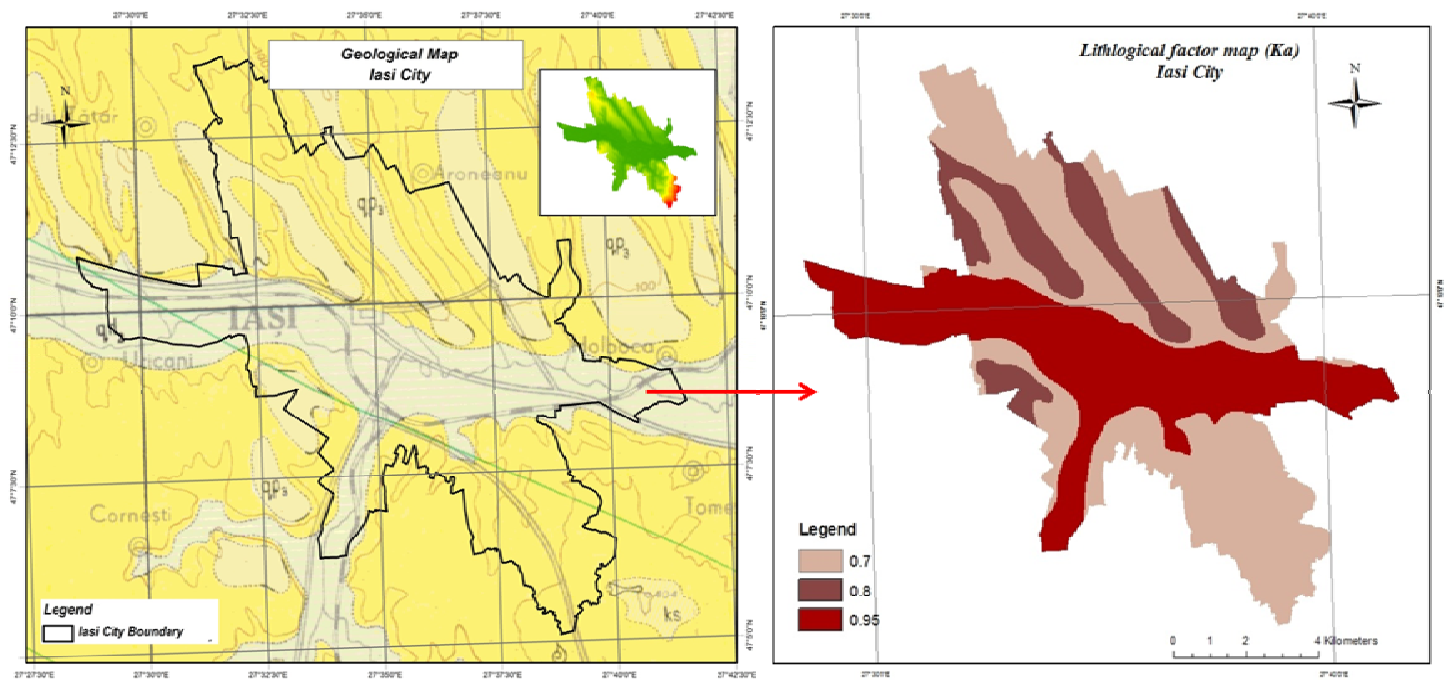

Fig. 1 - Geological Map/Lithological factor map, Iasi City (Ka)

\subsection{Geomorphological factor map}

The terrain geomorphology of the study area is characterized by heights between $20 \mathrm{~m}-370 \mathrm{~m}$ and slopes angle between $0^{\circ}-22^{\circ}$.

The geomorphological factor map results from reclassification of the terrain slopes raster. This raster is extracted from the digital terrain model using GIS Tools.

Digital terrain model has a $30 \mathrm{~m}$ resolution and was downloaded for free from SRTM online platform (Shuttle Radar Topography Mission) provided by NASA since 2005.

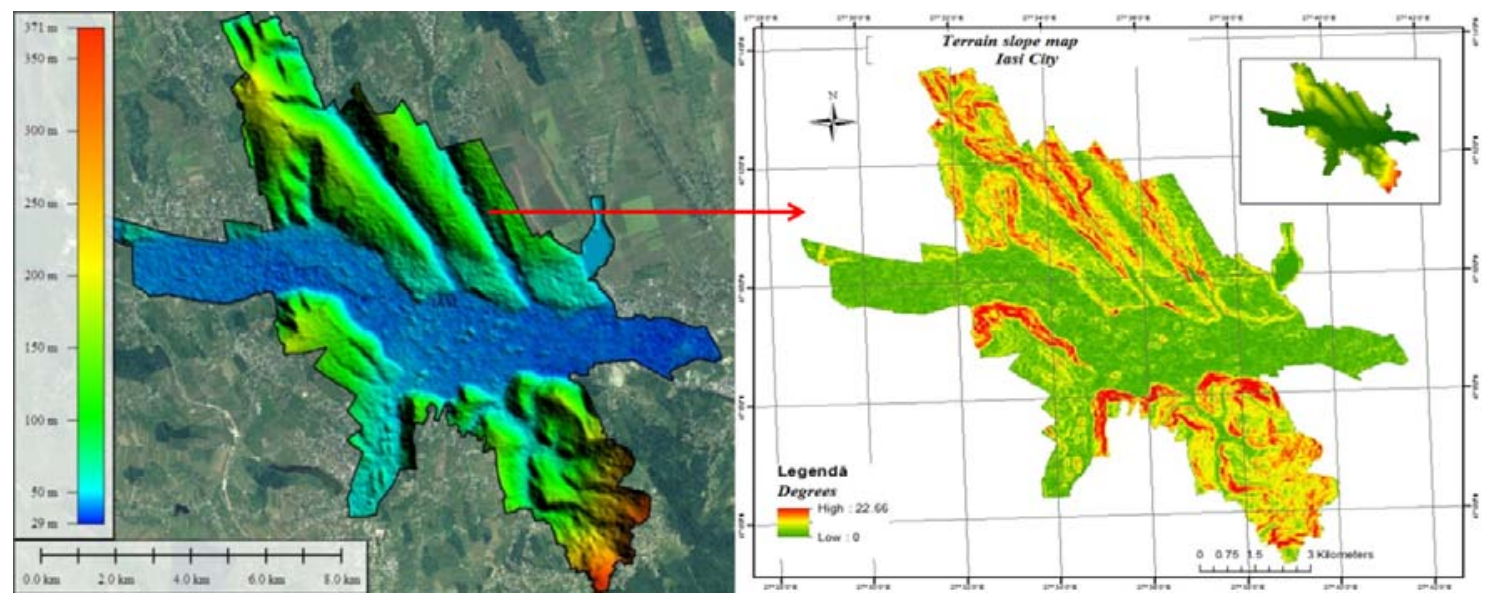

Fig. 2 - Digital terrain model / Slope Raster, Iasi City 
Slope classes are set as follows:

- $\quad$ slope between $0^{\circ}-5^{\circ}$

$\rightarrow \quad \mathrm{Kb}=0.05$

- slope between $5^{\circ}-10^{\circ} \rightarrow \mathrm{Kb}=0.4$

- $\quad$ slope between $10^{\circ}-20^{\circ} \rightarrow \quad \mathrm{Kb}=0.7$;

- slope greater than $20^{\circ} \quad \rightarrow \quad \mathrm{Kb}=0.9$.

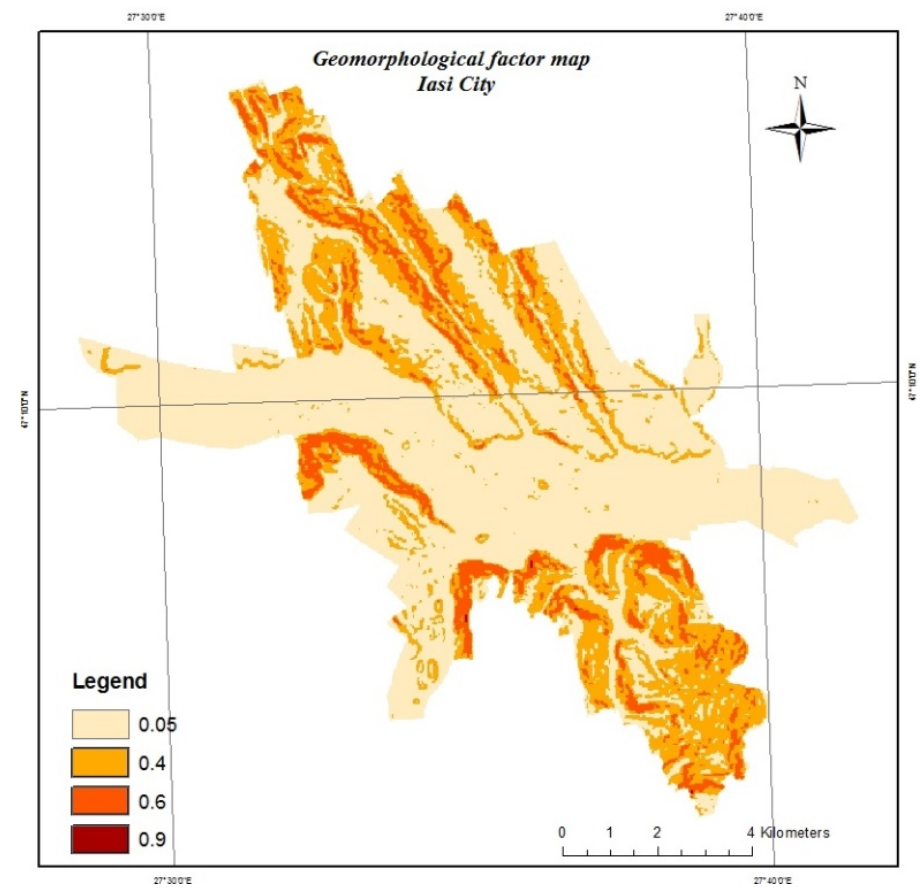

Fig. 3 - Geomorphological factor map, Iasi City (Kb)

\subsection{Structural factor map}

Structural factor map indicates an average probability of landslides occurrence $\left(\mathrm{K}_{\mathrm{c}}=0.30\right)$ for the entire city. This coefficient was estimated for post - bassarebian formations encountered on most of the territory.

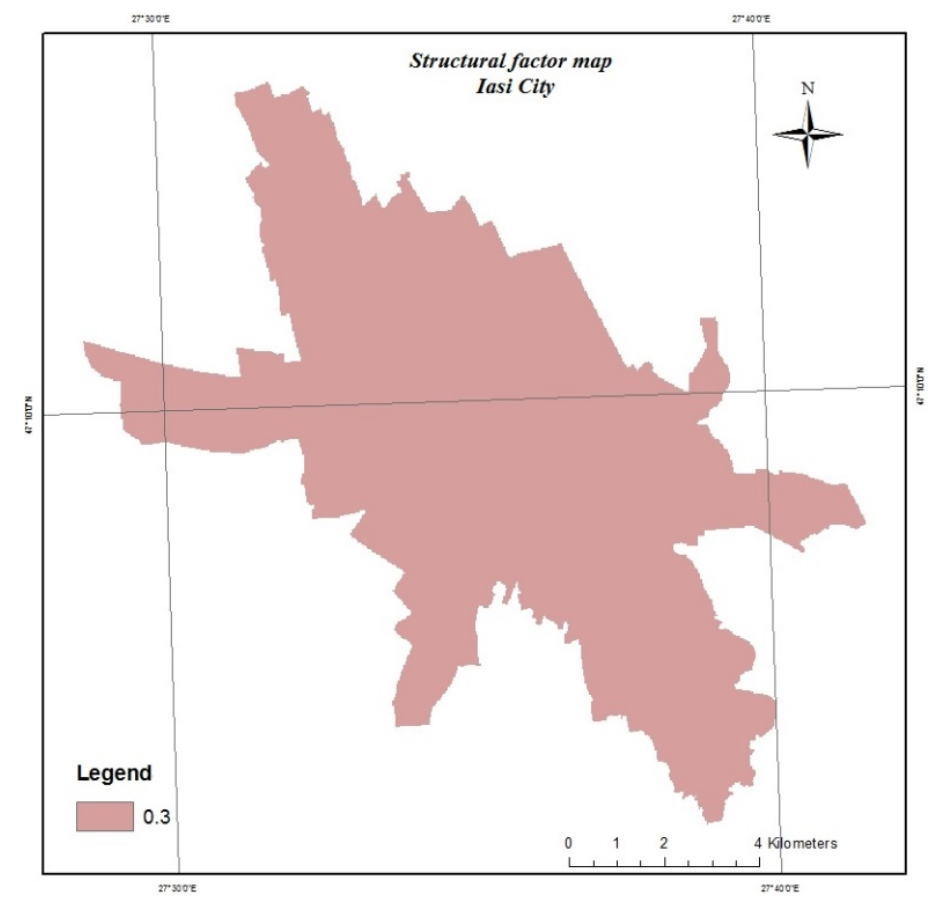

Fig. 5 - Structural factor map, Iasi City $\left(\mathrm{K}_{\mathrm{c}}\right)$ 


\subsection{Hydrological and climatic factor map}

Iasi city is situated in a region with average annual temperature of approximately 9-10 degrees and average annual rainfall between 500-600 $\mathrm{mm}$.

Hydro-climatic factor is assessed as: $\mathrm{K}_{\mathrm{d}}=0.5$.

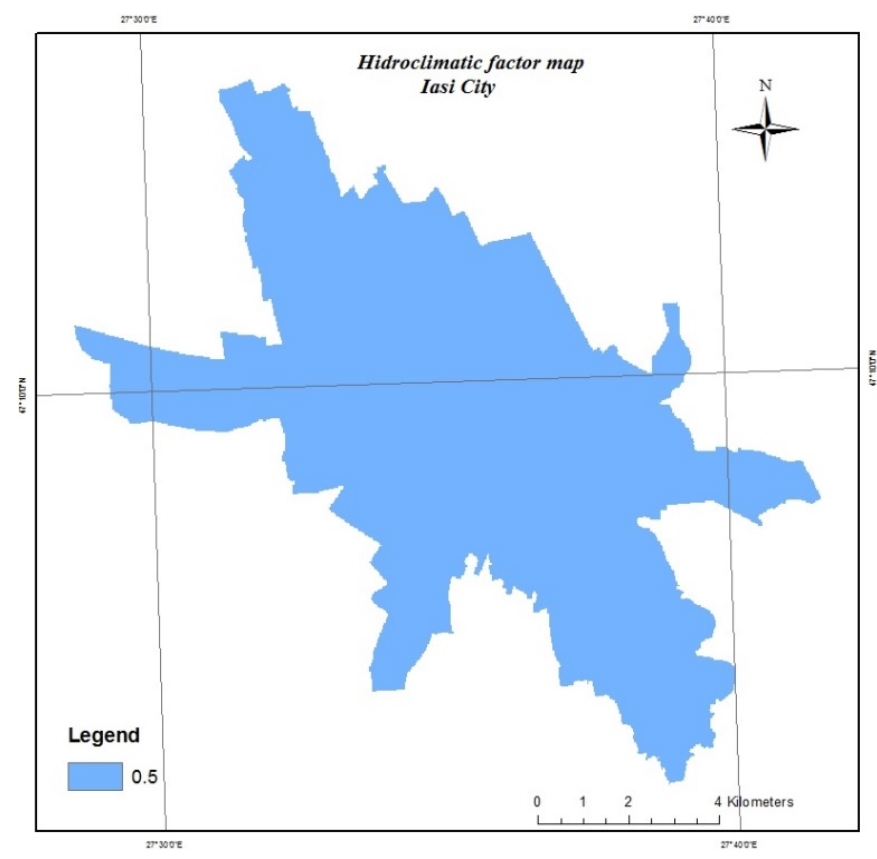

Fig. 6 - Hidro-climatic factor map, Iasi City $\left(\mathrm{K}_{\mathrm{d}}\right)$

\subsection{Hydrogeological factor map}

According to Hydrogeological Map of Romania, scale 1: 1000 000, Iasi city can be divided into two distinct macro regions with respect to groundwater level:

- groundwater table deeper than $5 \mathrm{~m} \quad \rightarrow \quad \mathrm{K}_{\mathrm{e}}=0.05$;

- groundwater table no deeper than $5 \mathrm{~m} \quad \rightarrow \quad \mathrm{K}_{\mathrm{e}}=0.4$.

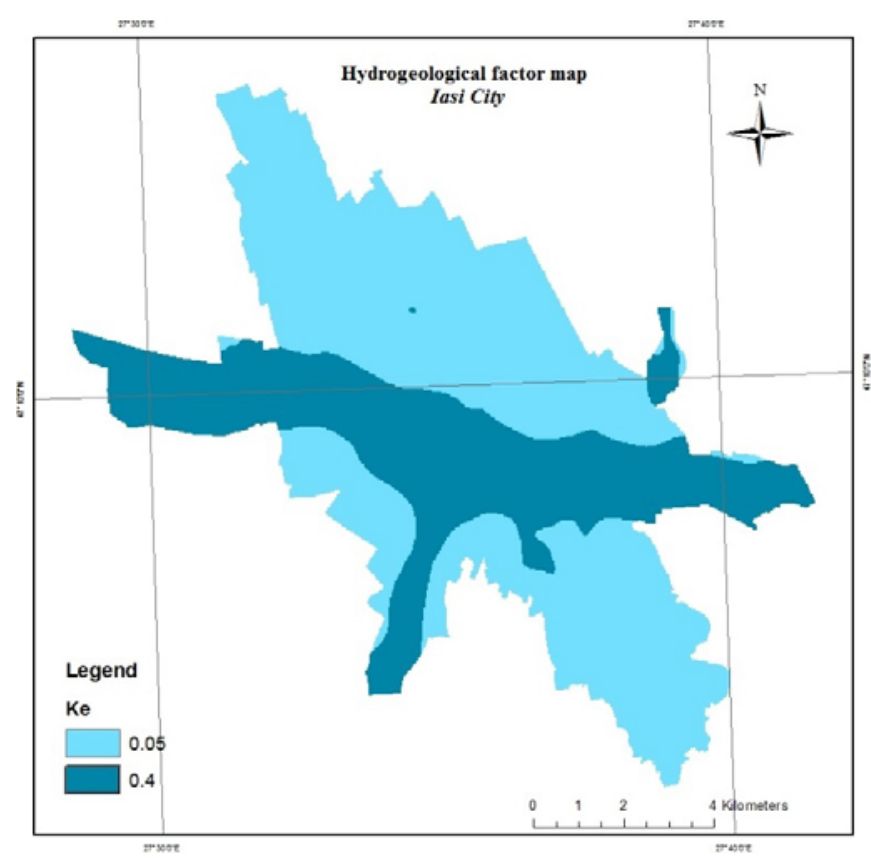

Fig. 7 - Hydrogeological factor map, Iasi City $\left(\mathrm{K}_{\mathrm{e}}\right)$ 


\subsection{Seismic factor map}

Taking into account the "Seismic Design Code - Part I - Provisions for buildings design" indicative P 100-1/2013", Iasi city corresponds to a seismic acceleration equal to $0.25 \mathrm{~g}$ (median earthquake recurrence interval 225 years). The corner period is $\mathrm{Tc}=0.7$ seconds.

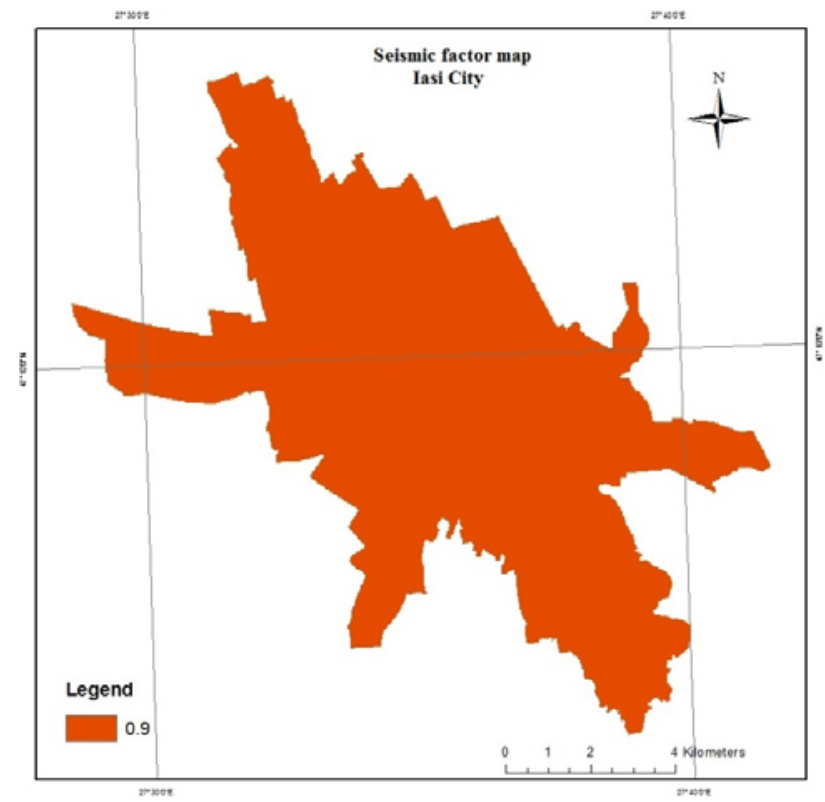

Fig. 8 - Seismic factor map, Iasi City $\left(\mathrm{K}_{\mathrm{f}}\right)$

\subsection{Land use factor map}

For land use factor mapping Corine Land Cover and orthophotos have also been used.

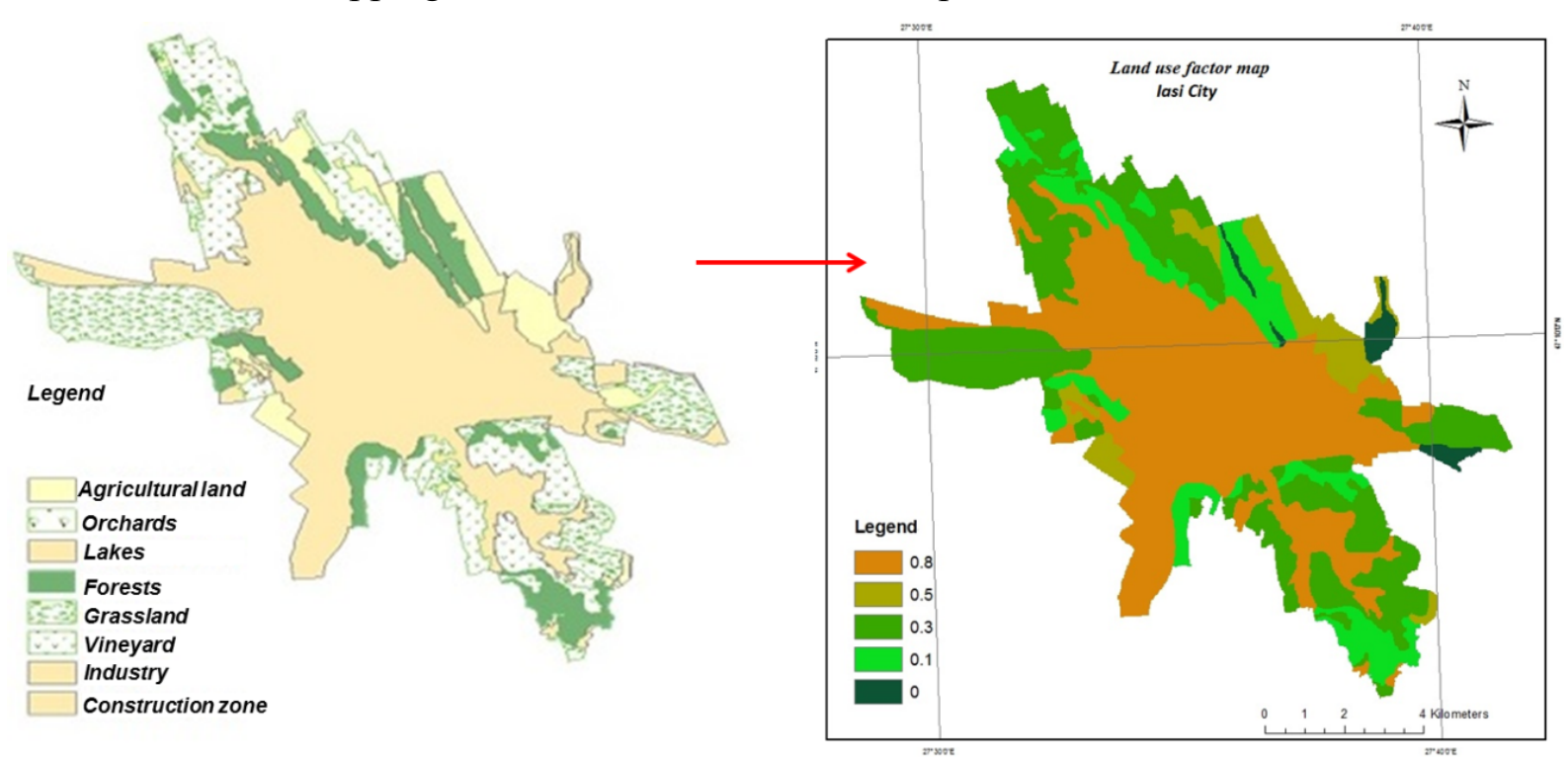

Fig. 9 - Land use factor map, Iasi City $\left(\mathrm{K}_{\mathrm{g}}\right)$

\subsection{Anthropic factor map}

For the anthropic element the following values were assigned:

- intravilan $\quad \mathrm{Kf}=0.8$

- extravilan $\quad \mathrm{Kf}=0.1$ 


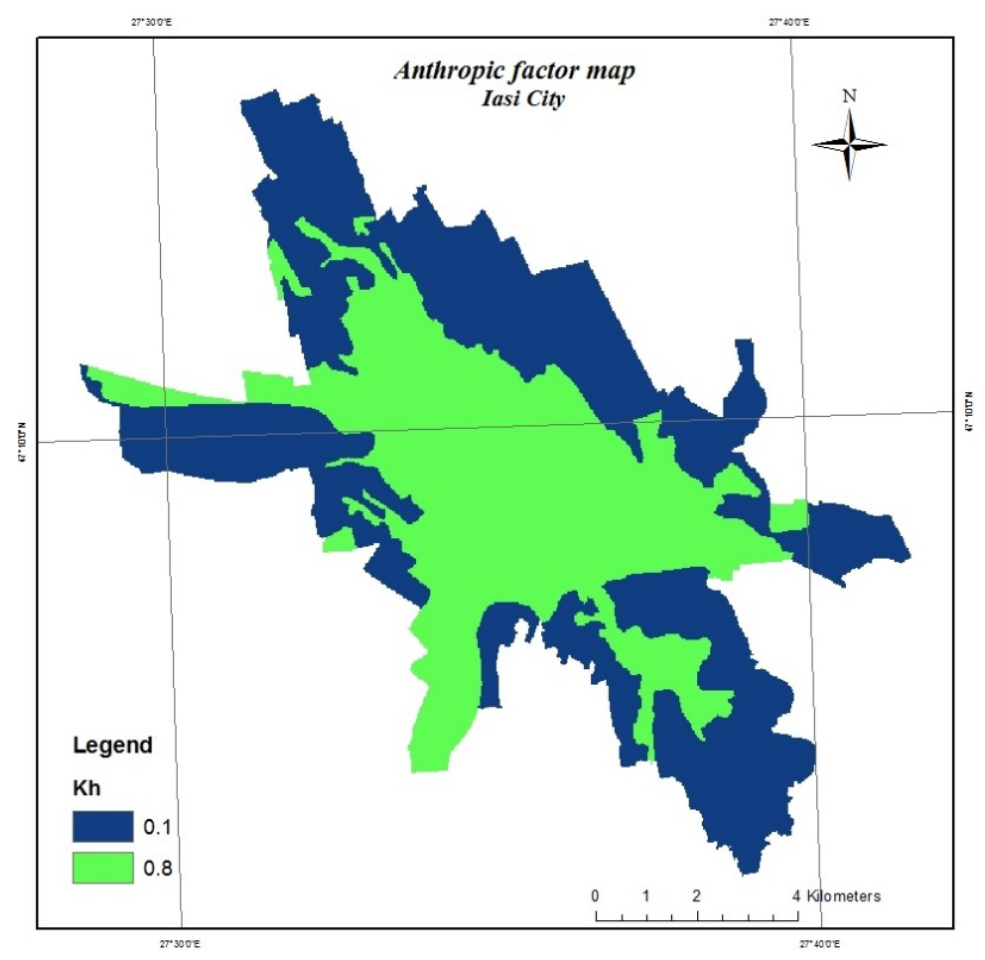

Fig. 10 - Anthropic factor map, Iasi City $\left(\mathrm{K}_{\mathrm{h}}\right)$

\subsection{Mean hazard rate map}

The mean hazard rate map (Fig. 11) has resulted from the overlapping of the 8 thematic maps, according to Equation 1.

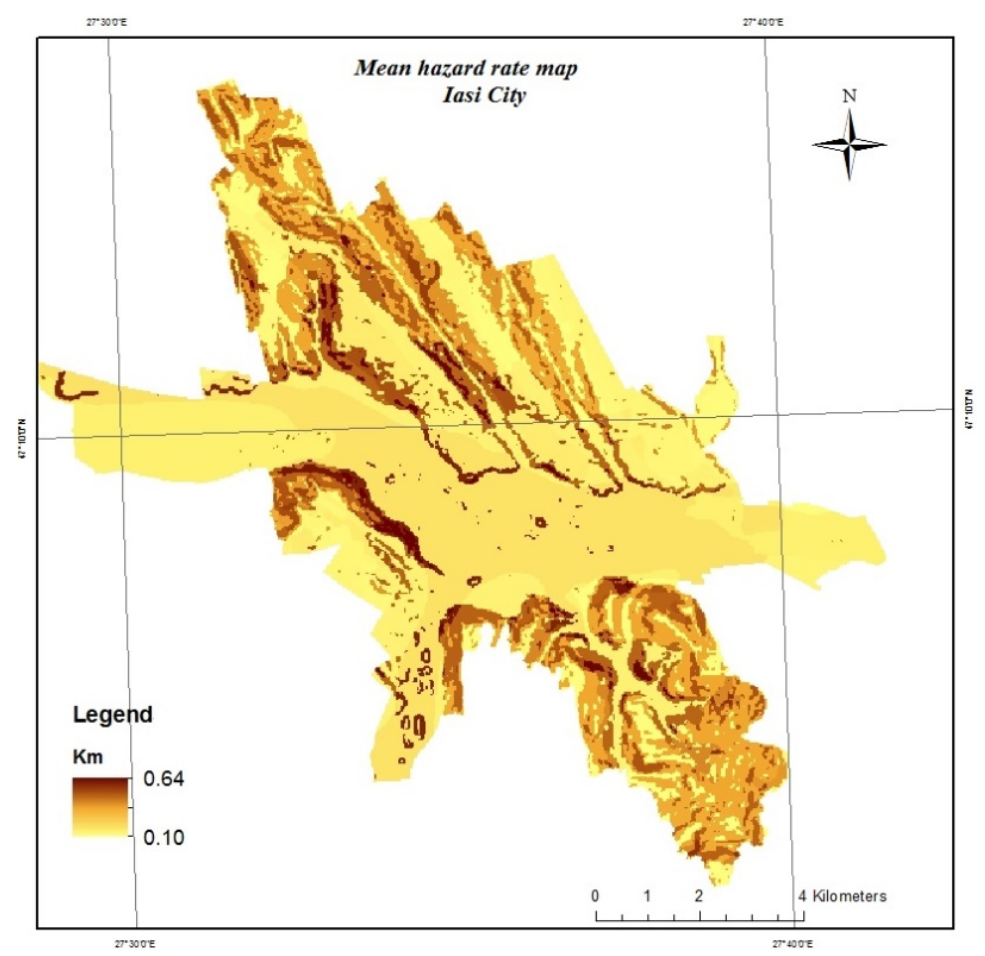

Fig. 11 - Mean hazard rate map, Iasi City (Km)

Further to reclassifying the last map according to Table 1 classes, the final landslide hazard map for Iasi city (Fig. 12) will result. 
Reclassification classes for $\mathrm{Km}$ values

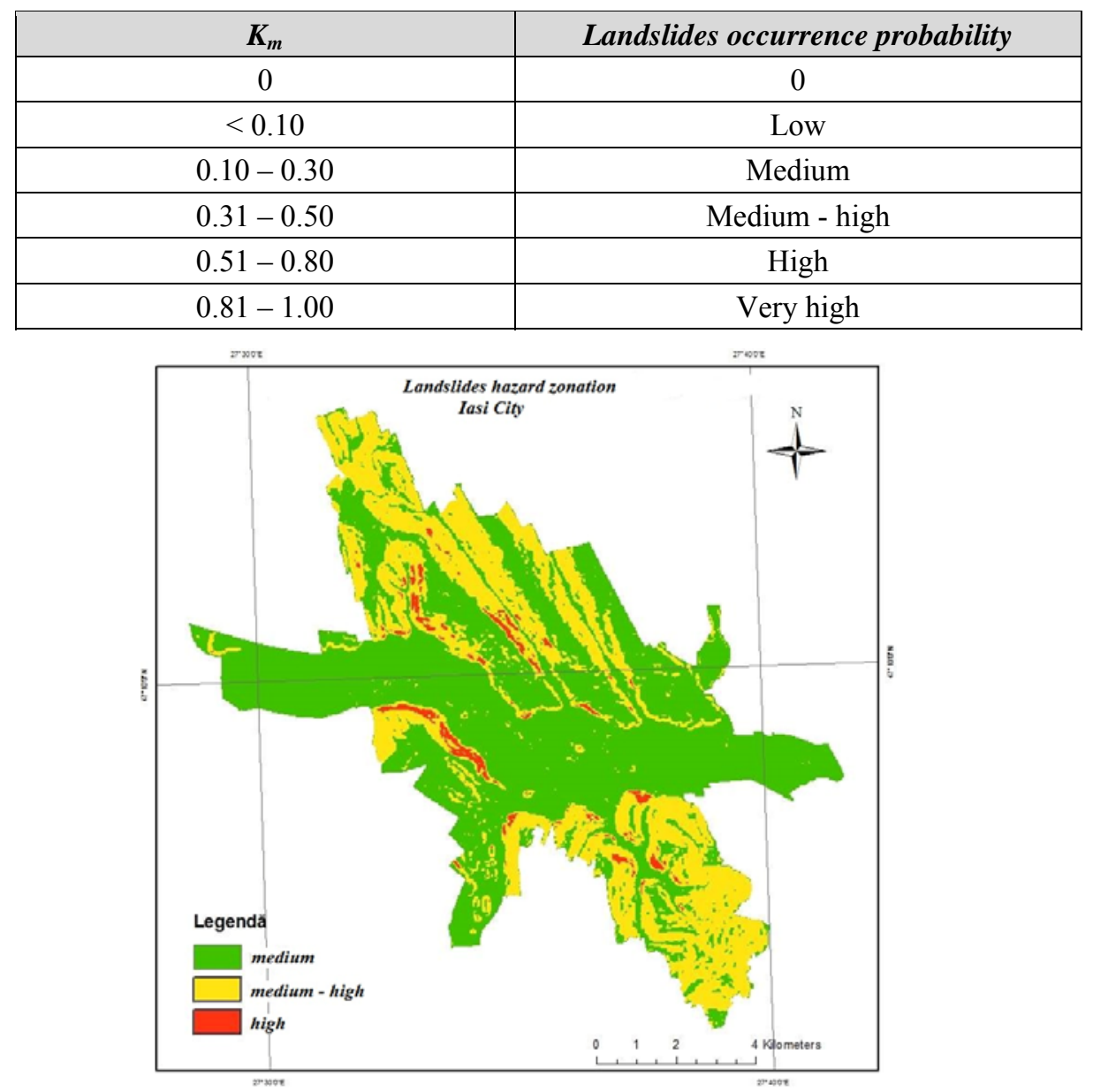

Fig. 12 - Landslide hazard map, Iasi City

\section{Landslides susceptibility zonation using the statistical method}

Susceptibility maps are also called relative hazard maps. The reason is the lack of the temporal component and the magnitude of the event.

In the second part of the paper, the bivariate statistical analysis is used, in order to generate the landslides susceptibility map, based on active events inventory. Landslide inventory maps show the spatial distribution of the landslides locations and the potential for future landslides.

The method involves intersections (combinations) between landslides inventory map and every map which reflects a certain parameter (trigger factor).

Bivariate analysis is using a basic, but effective, statistical method called hazard index method. It is one of the simplest methods but it can be easily applied in Geographic Information Systems.

Mathematical equation that underlies this analysis is presented below.

$$
P_{i}=\ln \left(\frac{\text { Densclasa }}{\text { Densharta }}\right)=\ln \left(\frac{\frac{\text { Area }\left(A_{i}\right)}{\text { Area }\left(F_{i}\right)}}{\frac{\text { Area }\left(A_{i}\right)}{\sum \text { Area }\left(F_{i}\right)}}\right)
$$

Where:

$i \quad$ classes in parameter map;

$F_{i} \quad$ weight (the importance) given to a parameter type; 
Densclasa landslides density within each class of parameter map;

Densharta landslide density within the entire parameter map;

$\operatorname{Area}\left(A_{i}\right) \quad$ total area occupied by landslides within each class of parameter map;

Area(Fi) total area occupied by each class of parameter map.

The analyzed factors (parameters) are slope, aspect, lithology, land use and soil.

Natural logarithm is used to provide negative values when landslides density is lower than normal and positive values when landslides density is higher than normal.

\subsection{Landslides inventory map}

The case study entails 42 landslides produced in Iasi city. The inventory was extracted from the scientific paper "The foundation of urban development decisions based on landslide hazard maps" [9].

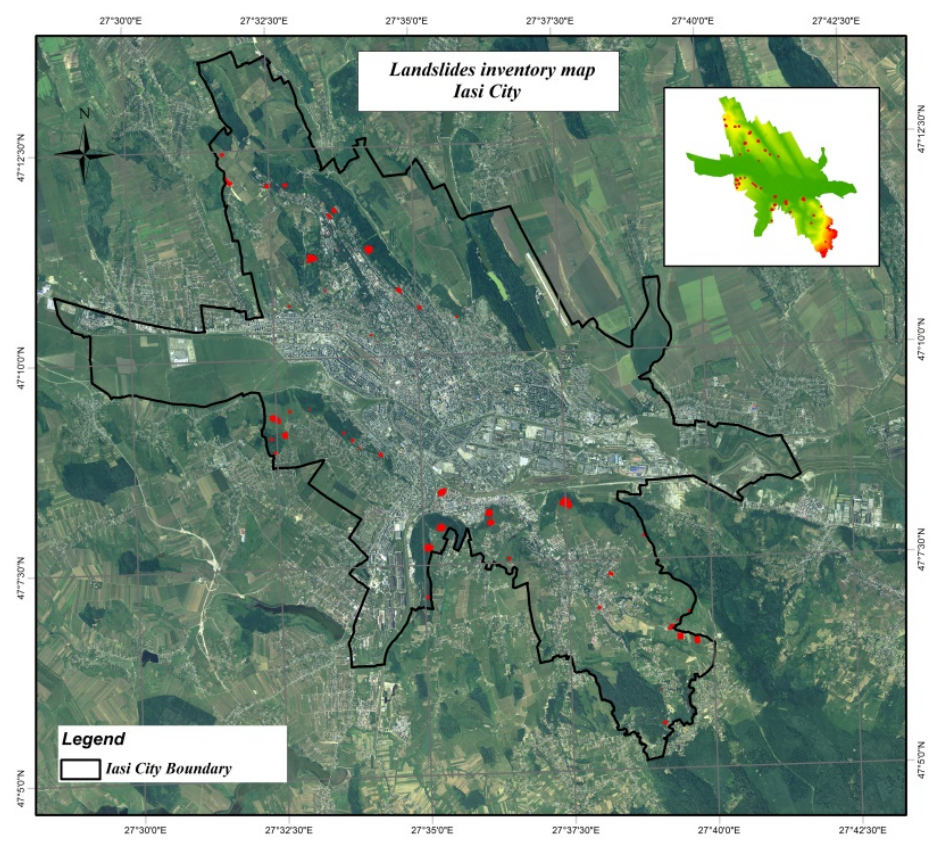

Fig. 13 - Landslide inventory map, Iasi City

\subsection{The overlap between the landslides inventory map and the slope parameter map (weights assessing)}

Slope map (Fig. 3) has been reclassified in 4 classes and each class weight has been evaluated according to Equation 1. See results from Table 2 and Fig. 14.

Calculation of landslides density associate to slope classes

\begin{tabular}{|c|c|c|c|c|c|c|c|}
\hline $\boldsymbol{i}$ & $\boldsymbol{F}_{\boldsymbol{i}}$ & $\boldsymbol{A}_{\boldsymbol{i}}$ & Densclasa & $\sum \boldsymbol{F}_{\boldsymbol{i}}$ & $\sum \boldsymbol{A}_{\boldsymbol{i}}$ & Densmap & $\boldsymbol{P}_{\boldsymbol{i}}$ \\
\hline $0^{\circ}-5^{\circ}$ & 63250 & 69 & $\mathbf{0 . 0 0 1 0 9}$ & 101223 & 576 & $\mathbf{0 . 0 0 5 5 9}$ & $\mathbf{- 1 . 6 5 1 7 7}$ \\
\hline $5^{\circ}-10^{\circ}$ & 29501 & 265 & $\mathbf{0 . 0 0 8 9 8}$ & 101223 & 576 & $\mathbf{0 . 0 0 5 5 9}$ & $\mathbf{0 . 4 5 6 5 2}$ \\
\hline $10^{\circ}-15^{\circ}$ & 7982 & 221 & $\mathbf{0 . 0 2 7 6 9}$ & 101223 & 576 & $\mathbf{0 . 0 0 5 5 9}$ & $\mathbf{1 . 5 8 2 1 9}$ \\
\hline $15^{\circ}-22^{\circ}$ & 490 & 21 & $\mathbf{0 . 0 4 2 8 6}$ & 101223 & 576 & $\mathbf{0 . 0 0 5 5 9}$ & $\mathbf{2 . 0 1 9 0 9}$ \\
\hline
\end{tabular}




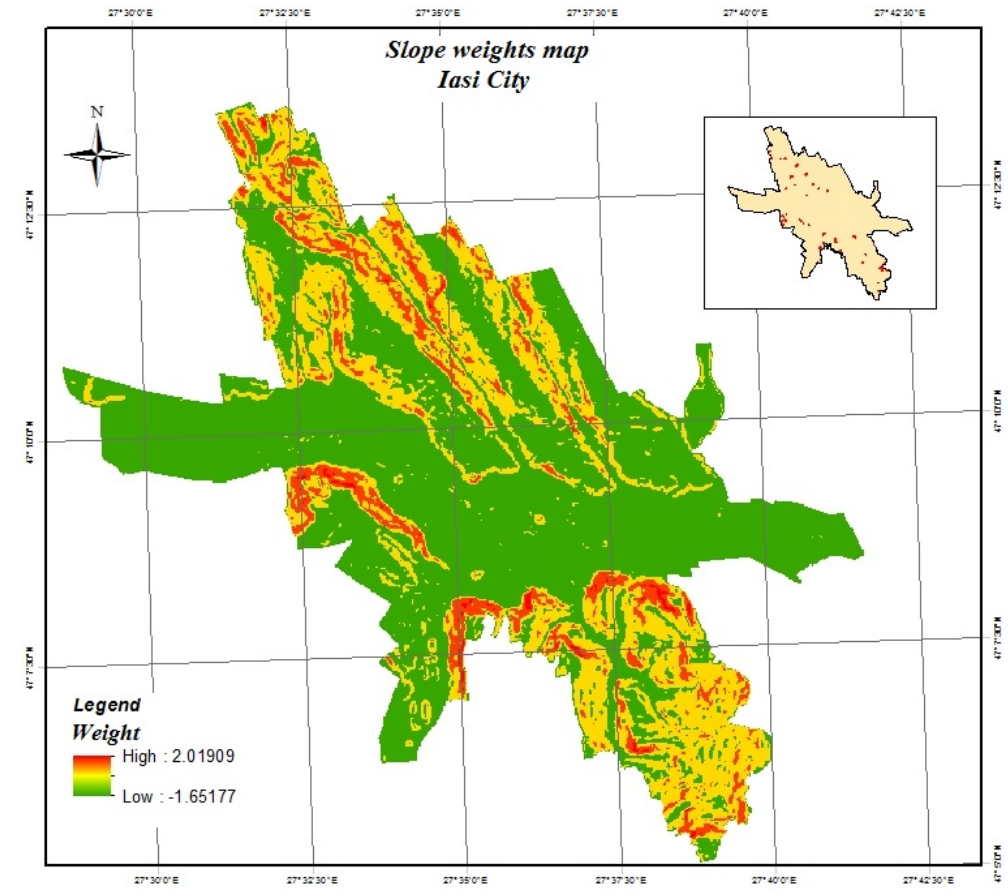

Fig. 14 - Slope weight map, Iasi City

\subsection{The overlap between the landslides inventory map and the aspect parameter map (weights assessing)}

Aspect map has been reclassified in 8 classes and each class weight has been evaluated according to Equation 1. See results from Table 3 and Fig. 16.

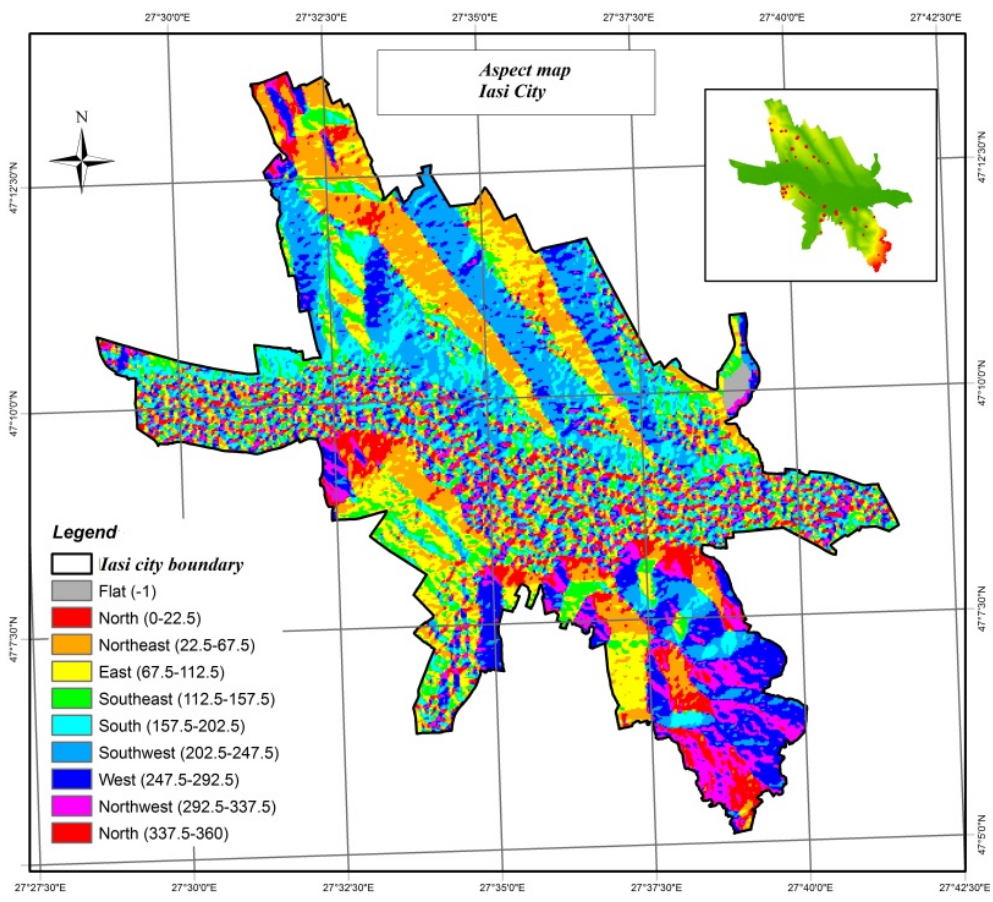

Fig. 15 - Aspect map, Iasi City 
Calculation of landslides density associate to aspect classes

\begin{tabular}{|c|c|c|c|c|c|c|c|}
\hline $\boldsymbol{i}$ & $\boldsymbol{F}_{\boldsymbol{i}}$ & $\boldsymbol{A}_{\boldsymbol{i}}$ & Densclasa & $\sum \boldsymbol{F}_{\boldsymbol{i}}$ & $\sum \boldsymbol{A}_{\boldsymbol{i}}$ & Densmap & $\boldsymbol{P}_{\boldsymbol{i}}$ \\
\hline $0^{\circ}-45^{\circ}$ & 12125 & 130 & 0.01072 & 101223 & 576 & 0.00559 & 0.63348 \\
\hline $45^{\circ}-90^{\circ}$ & 16851 & 94 & 0.00558 & 101223 & 576 & 0.00559 & -0.01990 \\
\hline $90^{\circ}-135^{\circ}$ & 10976 & 20 & 0.00182 & 101223 & 576 & 0.00559 & -1.13876 \\
\hline $135^{\circ}-180^{\circ}$ & 10446 & 18 & 0.00172 & 101223 & 576 & 0.00559 & -1.19463 \\
\hline $180^{\circ}-225^{\circ}$ & 15073 & 36 & 0.00239 & 101223 & 576 & 0.00559 & -0.86817 \\
\hline $225^{\circ}-270^{\circ}$ & 16523 & 124 & 0.00750 & 101223 & 576 & 0.00559 & 0.27675 \\
\hline $270^{\circ}-315^{\circ}$ & 8807 & 91 & 0.01033 & 101223 & 576 & 0.00559 & 0.59653 \\
\hline $315^{\circ}-360^{\circ}$ & 10422 & 63 & 0.00604 & 101223 & 576 & 0.00559 & 0.06043 \\
\hline
\end{tabular}

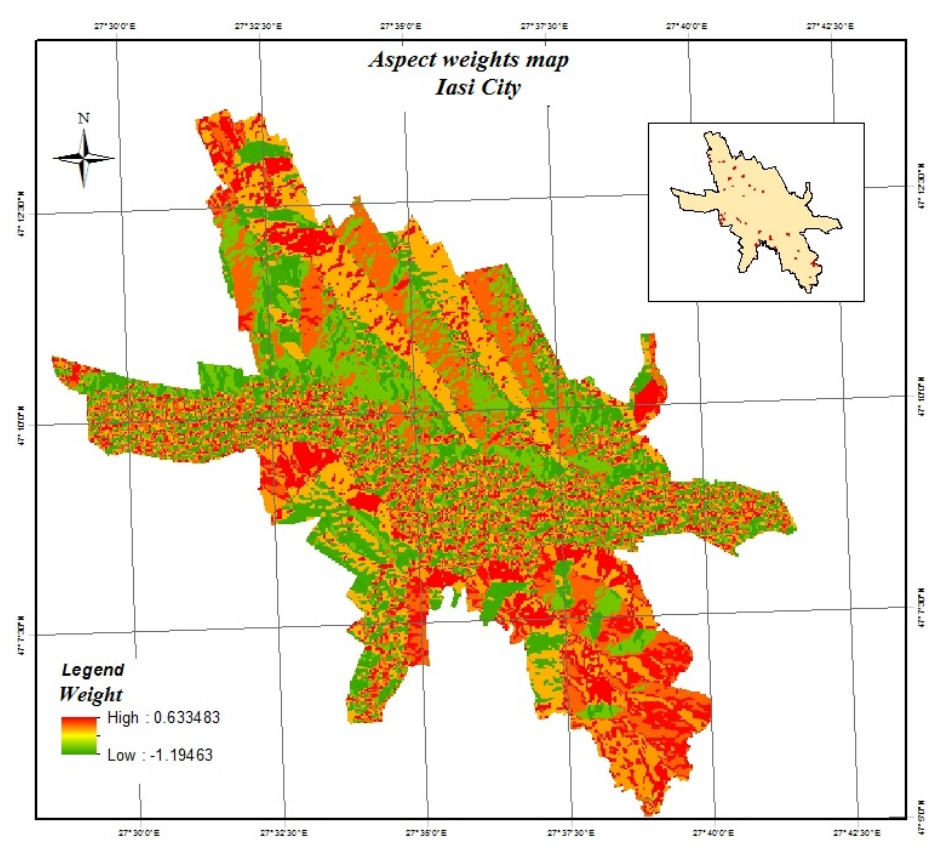

Fig. 16 - Aspect weight map, Iasi City

\subsection{The overlap between the landslides inventory map and the lithological map (weights assessing)}

Lithological map (Fig. 2) has been reclassified in 3 classes and each class weight has been evaluated according to Equation 1. See results from Table 4 and Fig. 17.

Table 4

Calculation of landslides density associate to lithological classes

\begin{tabular}{|c|l|l|l|l|l|l|l|}
\hline $\boldsymbol{i}$ & \multicolumn{1}{|c|}{$\boldsymbol{F}_{\boldsymbol{i}}$} & \multicolumn{1}{|c|}{$\boldsymbol{A}_{\boldsymbol{i}}$} & \multicolumn{1}{c|}{ Densclasa } & \multicolumn{1}{c}{$\sum \boldsymbol{F}_{\boldsymbol{i}}$} & $\sum \boldsymbol{A}_{\boldsymbol{i}}$ & $\boldsymbol{D}$ Densmap & $\boldsymbol{P}_{\boldsymbol{i}}$ \\
\hline bs & 45406213 & 379574 & 0.00836 & 91510245 & 509781 & 0.00559 & 0.40587 \\
\hline qp3 & 13533412 & 83183 & 0.00615 & 91510245 & 509781 & 0.00559 & 0.09835 \\
\hline qh2 & 32570620 & 47024 & 0.00144 & 91510245 & 509781 & 0.00559 & -1.35028 \\
\hline
\end{tabular}




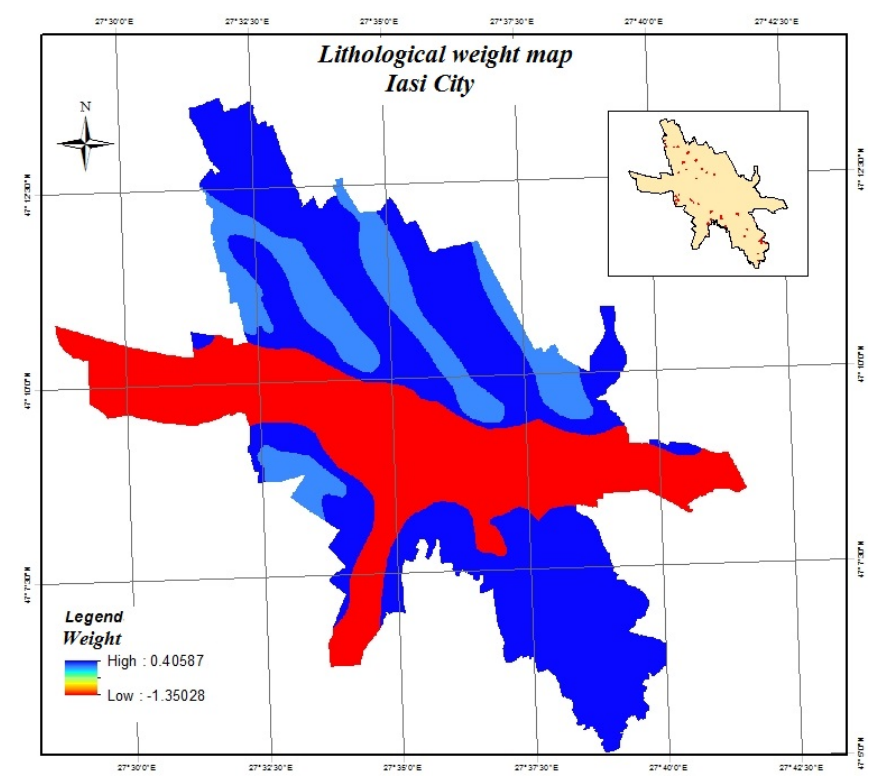

Fig. 17 - Aspect weight map, Iasi City

\subsection{The overlap between the landslides inventory map and the land use map (weights assessing)}

Land use map (Fig. 9) has been reclassified in 5 classes and each class weight has been evaluated according to Equation 1. See results from Table 5 and Fig. 18.

Table 5

Calculation of landslides density associate to land use classes

\begin{tabular}{|l|c|c|c|c|c|c|c|}
\hline \multicolumn{1}{|c|}{$\boldsymbol{i}$} & $\boldsymbol{F}_{\boldsymbol{i}}$ & $\boldsymbol{A}_{\boldsymbol{i}}$ & Densclasa & $\sum \boldsymbol{F}_{\boldsymbol{i}}$ & $\sum \boldsymbol{A}_{\boldsymbol{i}}$ & Densmap & $\boldsymbol{P}_{\boldsymbol{i}}$ \\
\hline Forest & 116961 & 2280 & 0.01949 & 914897 & 5111 & 0.00559 & 1.2498 \\
\hline Grassland & 291121 & 1581 & 0.00543 & 914897 & 5111 & 0.00559 & -0.0283 \\
\hline $\begin{array}{l}\text { Agricultural } \\
\text { land }\end{array}$ & 60023 & 46 & 0.00077 & 914897 & 5111 & 0.00559 & -1.9864 \\
\hline $\begin{array}{l}\text { Buildings and } \\
\text { Industry }\end{array}$ & 430243 & 1204 & 0.00280 & 914897 & 5111 & 0.00559 & -0.6913 \\
\hline Lakes & 16549 & 0 & 0 & 914897 & 5111 & 0.00559 & 0.0001 \\
\hline
\end{tabular}

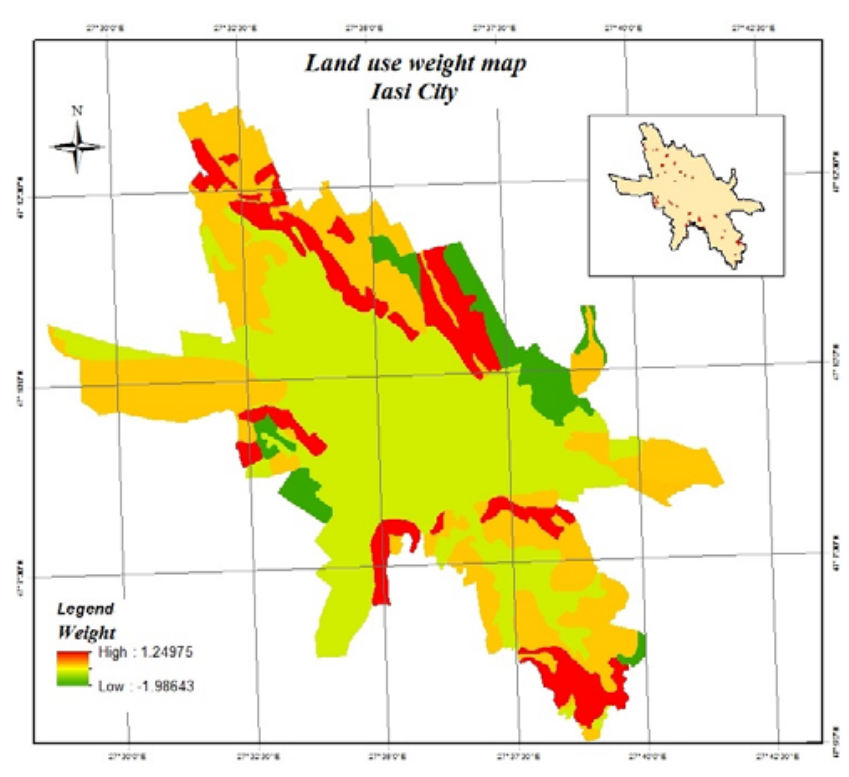

Fig. 18 -Land use weight map, Iasi City 
4.6 The overlap between the landslides inventory map and the soils map (weights assessing)

Soil map (Fig. 19) has been reclassified in 10 classes and each class weight has been evaluated according to Equation 1. See results from Table 6 and Fig. 20.

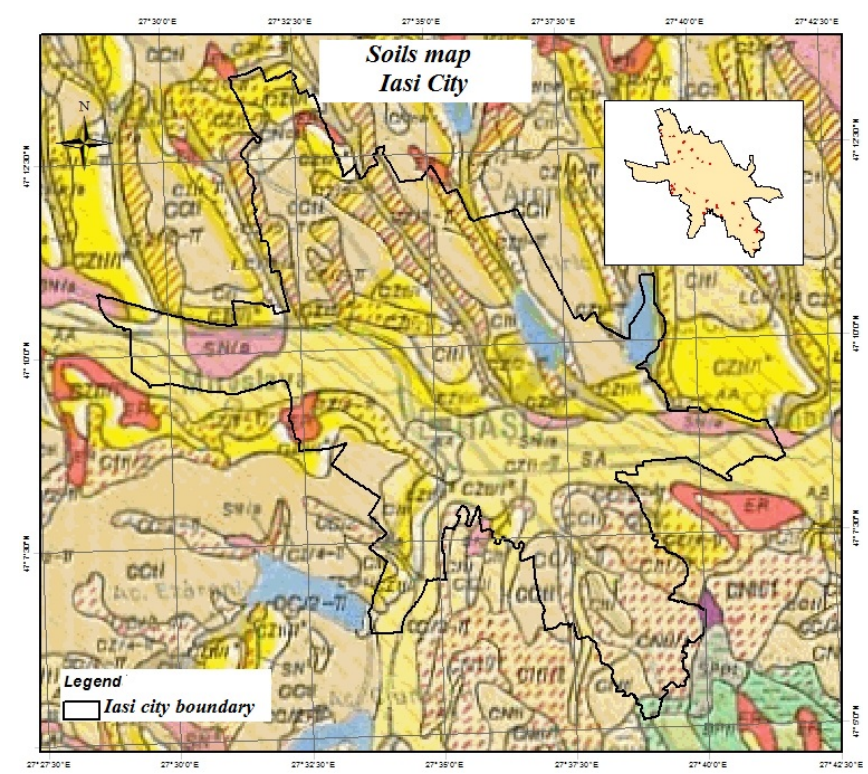

Fig. 19 -Soils map, Iasi City

Table 6

Calculation of landslides density associate to soils classes

\begin{tabular}{|c|c|c|c|c|c|c|c|}
\hline $\boldsymbol{i}$ & $\boldsymbol{F}_{\boldsymbol{i}}$ & $\boldsymbol{A}_{\boldsymbol{i}}$ & Densclasa & $\sum_{\boldsymbol{i}}$ & $\boldsymbol{F}_{\boldsymbol{i}} \boldsymbol{A}_{\boldsymbol{i}}$ & Densmap & $\boldsymbol{P}_{\boldsymbol{i}}$ \\
\hline AA & 11343 & 253 & 0.022305 & 914897 & 5111 & 0.00559 & 1.38445 \\
\hline Lakes & 26234 & 0 & 0 & 914897 & 5111 & 0.00559 & 0.0001 \\
\hline CC & 143555 & 517 & 0.003601 & 914897 & 5111 & 0.00559 & -0.43901 \\
\hline CM & 165931 & 1006 & 0.006063 & 914897 & 5111 & 0.00559 & 0.081826 \\
\hline CN & 109847 & 1406 & 0.0128 & 914897 & 5111 & 0.00559 & 0.829077 \\
\hline CY & 170096 & 443 & 0.002604 & 914897 & 5111 & 0.00559 & -0.76313 \\
\hline ER & 9467 & 686 & 0.072462 & 914897 & 5111 & 0.00559 & 2.562727 \\
\hline SA & 233067 & 800 & 0.003432 & 914897 & 5111 & 0.00559 & -0.48705 \\
\hline SN & 42886 & 0 & 0 & 914897 & 5111 & 0.00559 & 0.0001 \\
\hline BP & 2471 & 0 & 0 & 914897 & 5111 & 0.00559 & 0.0001 \\
\hline
\end{tabular}

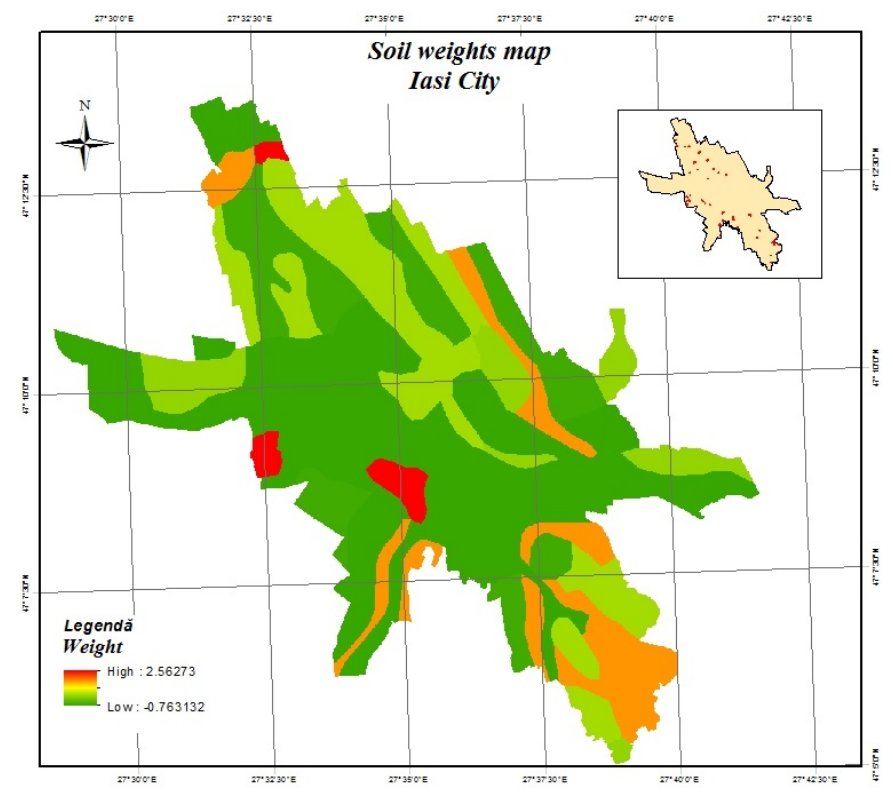

Fig. 20 -Soils weight map, Iasi City 


\subsection{Landslides susceptibility map}

The final susceptibility map results by summing the 5 weights parameters maps previously determined.

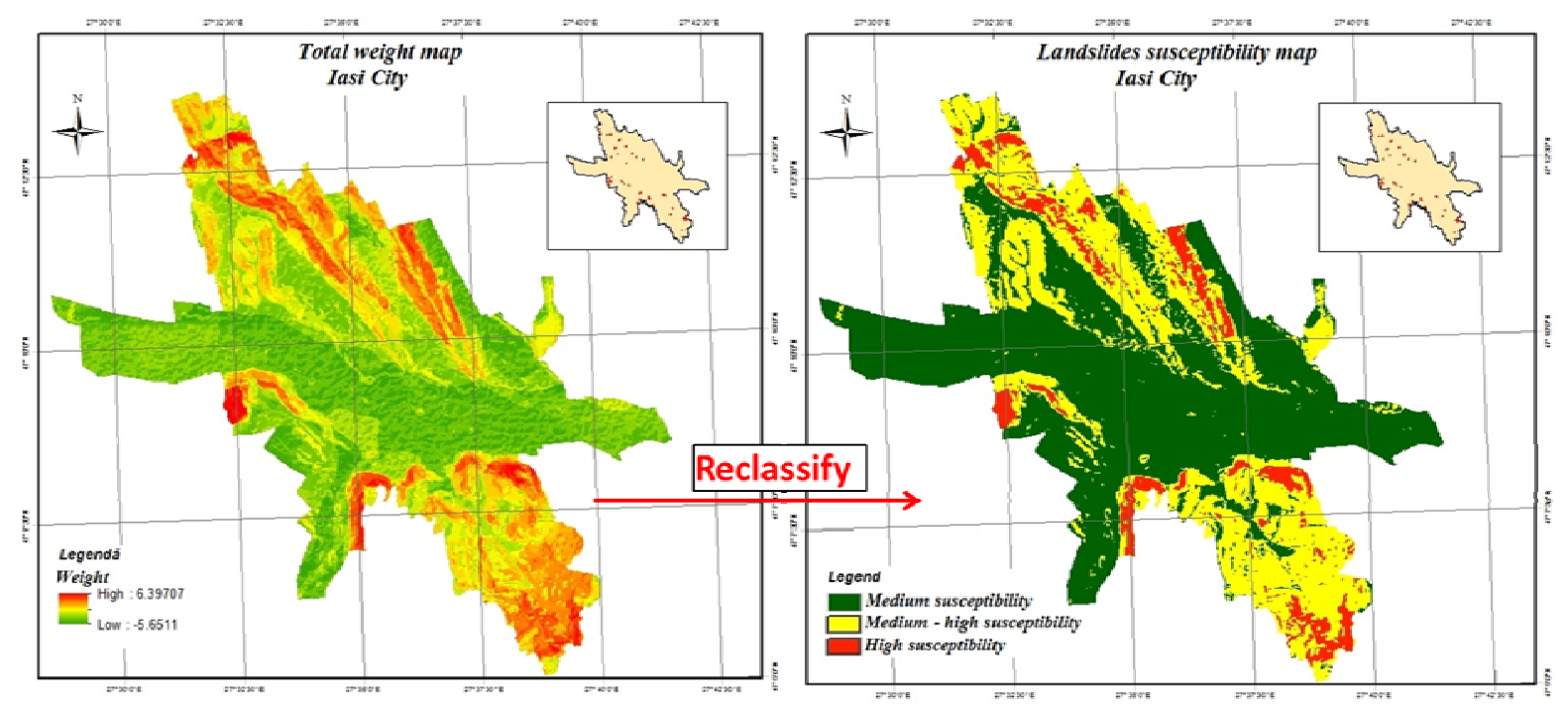

Fig. 20 - Landslides susceptibility map, Iasi City

\section{Conclusions}

For the landslide hazard assessment in Iasi city, two GIS models were developed, approaching two different types of analyses: the mean hazard rate methodology and the bivariate statistical analysis.

Further to the application of the national methodology a medium probability of landslides occurrence results for more than $60 \%$ of the entire city surface. Note that the precision of the maps, firstly, depends on the accuracy of input data and secondly by the user relative subjectivity in the evaluation process of the 8 factors.

Susceptibility map achieved from the statistical model is calculated by summing the weights of importance of each analyzed parameter. The number of susceptibility classes of the final map is set by the user and depends of the analysis purpose, comparatively with previous methodology whose classes number is fixed (by $\mathrm{K}_{\mathrm{m}}$ ). Therefore, susceptibility maps reclassification has no common rule for all users and this can lead to a high degree of uncertainty.

Susceptibility map was reclassified on 3 levels in order to achieve a comparative analysis between the two approaches. Approaching statistical method, it is ascertained that the areas with medium high potential and high potential for landslides occurrence are noticeably extended (Fig. 21).

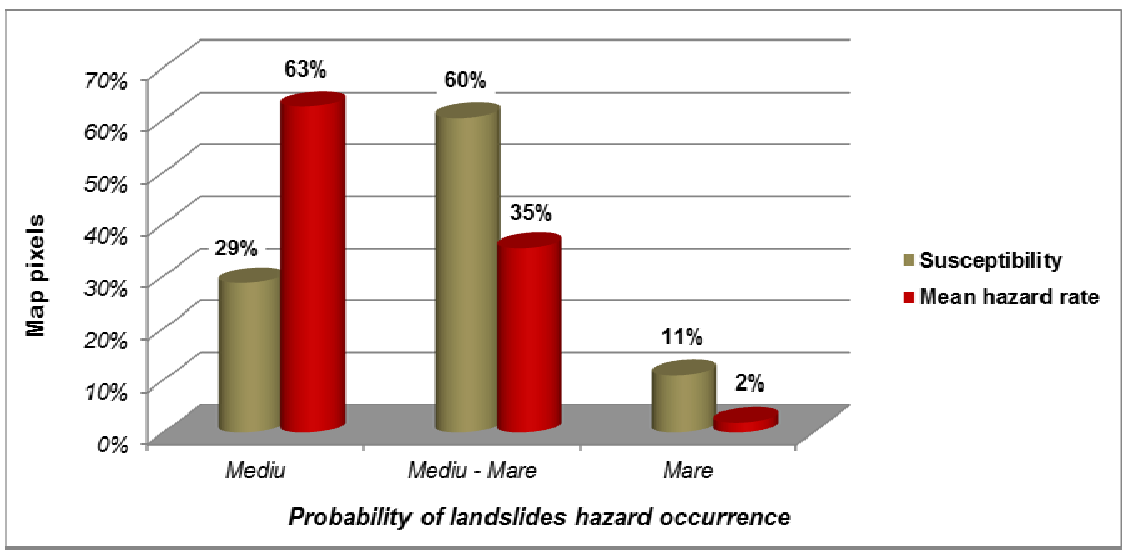

Fig. 21 - Probability of landslides hazard occurrence - pixels analysis, Iasi City 
The main advantage of the statistical method is the possibility of performing analyses on certain types of landslides (if needed) and considering only the parameters that influence the phenomenon of instability (e.g. erosional landslides, falls, primary or reactivated landslides etc.). Nevertheless, this requires a thorough inventory of events.

Due to the large spectrum of landslide phenomena, it is very difficult to define one single methodology for identifying, assessing and mapping landslide hazards, and to evaluate the associated risk.

These types of maps can be used by the municipalities in order to highlight the landslides highpotential areas.

For other types of hazard, for example, earthquakes and floods, temporal component (frequency of occurrence) and the magnitude of the phenomenon are known. For landslides case, it is difficult to determine or estimate this and it still leaves room for further research.

\section{References}

[1] Manea, S. (2009). Evaluarea riscului de alunecare a versanţilor, Ed. Conpress

[2] Brabb EE, Pampeyan EH (1972). Preliminary map of landslide deposits in San Mateo County, California. US Geological Survey Miscellaneous Field Studies, Map MF-360, scale 1:62.500 (reprinted in 1978)

[3] Legea nr. 575/2001 privind aprobarea Planul de Amenajare a Teritoriului Naţional - PATN - Secţiunea a V-a, Zone de risc natura;

[4] Marchidanu, E. Geologie pentru ingineri constructori cu elemente de protecție a mediului geologic și geologie turistică;

[5] Guzzetti F, Carrarra A, Cardinali M, Reichenbach P, (1999). Landslide hazard evaluation: are view of current techniques and their application in a multi-scale study, Central Italy. Geomorphology;

[6] Varnes, D.J., (1984), Landslide hazard zonation: a review of principles and practice;

[7] Van Westen, C.J., Van Asch, T.W.J., Soeters, R.. (2006). Landslide hazard and risk zonation: why is it still so difficult: Bulletin of Engineering Geology and the Environment, 65, 167-18;

[8] Akgun A, Turk N, (2010). Landslide susceptibility mapping for Ayvalik (Western Turkey) 379 and its vicinity by multi criteria decision analysis. Env Earth Sci 61(3):595-611;

[9] Adomniţei, C., (2010). Fundamentarea deciziilor de dezvoltare urbană pe baza hăților de hazard la alunecare, Universitatea Tehnică "Gheorghe Asachi” din Iași, Teză de doctorat. 